Relations industrielles

Industrial Relations

\title{
The Canadian Congress of Labour
}

\section{Eugène Forsey}

Volume 4, numéro 1, septembre 1948

URI : https://id.erudit.org/iderudit/1023429ar

DOI : https://doi.org/10.7202/1023429ar

Aller au sommaire du numéro

\section{Éditeur(s)}

Département des relations industrielles de l’Université Laval

\section{ISSN}

0034-379X (imprimé)

1703-8138 (numérique)

Découvrir la revue

Citer cet article

Forsey, E. (1948). The Canadian Congress of Labour. Relations industrielles / Industrial Relations, 4(1), 5-9. https://doi.org/10.7202/1023429ar

Tous droits réservés @ Département des relations industrielles de l’Université Laval, 1948
Ce document est protégé par la loi sur le droit d'auteur. L'utilisation des services d'Érudit (y compris la reproduction) est assujettie à sa politique d'utilisation que vous pouvez consulter en ligne.

https://apropos.erudit.org/fr/usagers/politique-dutilisation/ 
tical action, and it is quite acceptable. This attitude, the C.T.C.C. intends to maintain.

The C.T.C.C. wants to remain a national power. It believes in the necessity of a fully autonomous Canadian trade-unionism, which can see for itself its own problems. It rejects as contrary to our national interest any subordination - either direct or indirect - to American trade-unionism.

Finally, it believes that trade-unionisin ought to be entirely national in its origin, its inspiration and its trend, if it wants to adapt its political, economic and social action to the best interest of the national economy, for the realization of the common good.

The Canadian and Catholic Confederation of Labour has gained for itself a reputation of uprightness. It is listened to with increasing interest by the governments. Its contribution to the Christian social restoration of the country is of the finest quality, and should not be underestimated.

\title{
THE CANADIAN CONGRESS OF LABOUR
}

\author{
Eugene Forsey
}

The Canadian Congress of Labour is the younger and slightly smaller of the two major central labour organizations in Canada. The Trades nad Labor Congress was founded in 1873, and by 1946 had about 356,000 members. The Canadian Congress of Labour was founded in 1940, and by 1946 had about 315,000 members.

The two Congresses differ not only in age and size but also in several much more important ways.

First, their basis of organization. 'The Trades and Labor Congress has some industrial unions, notably the International Ladies Garment Workers' Union and the Canadian Seamen's Union. But most of its membership is in craft unions. Plumbers are organized as plumbers, carpenters as carpenters, electricians as electricians, regardless of the particular job they work at.

This difference is very important. It is one of the main reasons why the C.C.L. grew from 70,000 to 315,000 members in six years, while the T.L.C. grew only from about 200,000 to 356,000 . The craft form of organization is not suited to modern mass production industry, where great corporations face large groups of semi-skilled or unskilled workers. Most of these workers have no craft. The attempt to organize them on a craft basis simply means that the big, powerful employer

Note of the Editors: This article was written a few months ago and no account has been made of changes which have occurred since. faces a scattering of small, weak unions, or none at all. Until a dozen years ago, the mass production industries in this country were almost wholly unorganized. The Dominion Department of Labour's Report on Labour Organization for 1935 does not even list the Automobile Workers, or the Iron, Steel and Tin Workers, the predecessors of the United Steelworkers, or the Woodworkers. As late as 1940, the Mine, Mill and Smelter Workers had only 176 members, the Packinghouse Workers' Organizing Committee only 221, the Rubber Workers 610, the Electrical, Radio and Machine Workers 637. By 1946, the Automobile Workers were the largest union in Canada, with 50,000 members; the Steelworkers came next, with 35,000 ; the Woodworkers were fourth, with 27,000; the Electrical, Radio and Machine Workers, with 22,000 and the Mine, Mill and Smelter Workers, with 21,675 , were practically tie with the Mine Workers and the Machinists for sixth place; the Packinghouse Workers had 17,000 members; the Rubber Workers had nearly 10,000 . It is hardly too much to say that in these industries industrial unionism wrought a revolution in a single decade, transforming them from a state of almost total lack of organization to one where practically all the important enterprises were under union agreements. In many instances, what were citadels of anti-unionism have become strongholds of unionism. The Trades and Labor Congress had met with little success in its occasional attempts to organize the unorganized, largely because its basis of organization was not suited to the task. The 
Canadian Congress of Labour has won a series of really amazing victories, largely because its basis of organization was suited to the task.

A second important difference between the two Congresses is that the Canadian Congress of Labour is autonomous, while the Trades and Labor Congress is not. Both Congresses are made up predominantly of international unions, with headquarters in the United States and affiliated with the two major American central labour bodies, the A.F.L. and C.I.O. But there the resemblance ends.

The Canadian Congress of Labour has within it a strong tradition of purely Canadian unionism. Its President, Mr. A. R. Mosher, is the founder and head of the largest, and once of the oldest, purely Canadian unions, the Canadian Brotherhood of Railway Employees and Other Transport Workers. The Congress was formed as a merger of the purely Canadian All-Canadian Congress of Labour with the Canadian branches of C.I.O. unions, and the All-Canadian Congress agreed to the merger only in the distinct understanding that the new Congress, and the international unions in it, were to have complete autonomy. The Congress was not formed or chartered by the C.I.O., is not affiliated with the C.I.O., does not pay dues to the C.I.O., and is in no way controlled by the C.I.O., in any aspect of its domestic or external affairs. The Congress may charter or admit to affiliation, unions which are «dual» to C.I.O. unions, and has done so. It may refuse to accept the affiliation of C.I.O. unions, and has done so. Jurisdictional disputes between its affiliated international unions are settled not by C.I.O. but by C.C.L. Of the Executive Comittee of nine, three (including the President) are members of purely Canadian unions; two (including the Secretary-Treasurer) are members of the United Mine Workers of America (unaffiliated in the United States); four are members of unions which, in respect of their United States members are affiliated with and pay dues to the C.C.L.

The C.C.L.'s complete independence from C.I.O. control is perhaps most obvious in the history of its relations with the United Mine Workers. When the C.C.L. was formed, the U.M.W. was part of the C.I.O. in the United States; its international President, Mr. Lewis, being President of the C.I.O. In 1942, the U.M.W. left the C.I.O., but stayed in the C.C.L. In 1946, it affiliated with the A.F.L., but still stayed with the C.C.L. In
1947, it left the A.F.L., but still stayed with the C.C.L. For six years the U.M.W. and the C.I.O. unions in the United States have been fighting each other tooth and nail, but the Canadian branches of the same organizations have been peacefully co-operating in the C.C.L.

The Trades and Labor Congress has its purely Canadian unions too, and one powerful international union, the Machinists, which in the United States is unaffiliated. For some years its Secretary-Treasurer, Mr. Pat Sullivan, was a member of a purely Canadian union, the Seamen; and its President Mr. Bengough, is a member of the Machinists. It is noteworthy that when the A.F.L., a year or so ago, tried to get the T.L.C. to expel the Machinists, the attempt failed. On the other hand, the T.L.C., by its constitution, is bound not to accept the affiliation of any union \&dual 》 to an A.F.L., union, and jurisdictional disputes between A.F.L. unions affiliated with the T.L.C. are settled by the A.F.L., not the T.L.C. The Canadian Congress of Labour itself is a by-product of the T.L.C.'s lack of autonomy. When the A.F.L. expelled the C.I.O. unions in the United States, the T.L.C. was very reluctant to follow suit, and delayed as long as it could. But when the A.F.L insisted, the T.L.C. was obliged to toe the line. The alternative would have been the secession of the A.F.L. unions. In the more recent Machinists' case there was no question of a rival central organization or dual unionism; in the C.I.O. case there was.

A third important difference between the two Congresses is in their positions on Labour political action. The T.L.C. refuses to endorse any political party. The C.C.L. in 1943 endorsed the C.C.F. as «the political arm of Labour in Canada » and commended that all its affiliated and chartered unions affiliate with the C.C.F. It has reaffirmed this decision at each convention since, and has set up Political Action Committees to implement it. Numerous leaders of C.C.L. unions have been C.C.F. candidates or members of provincial Legislatures, and the Ontario Federation of Labour (Ontario section of the C.C.L.) took a very active part in the recent Ontario election. ce?

What are the reasons for this sharp differen-

Undoubtedly one important reason is the American influence on Canadian unions. This also helps to explain why comparatively few C.C.L. unions have accepted the recommendation 
to affiliate with the C.C.F. The policy of A.F.L. and C.I.O. alike has been the Gompers policy: reward Labour's friends and punish Labour's enemies individually.

This policy makes some kind of sense in the United States. The President and his Cabinet are outside Congress and are not responsible to it. The President and the two Houses are elected for fixed terms, and the terms are different. Consequently, the Administration may, as at present, be of a different political party from the majority in the Senate or the House or both. But neither the Senate nor the House nor both together can get rid of the President before his term is up, except by impeachment, which is practically out of the question. And the President cannot get rid of the Senators or Representatives before their term is up. Moreover, thanks to the peculiar method of electing the President, it is perfectly possible for a President of one party to face a House or Senate or both controlled by the other party for the whole of his term. Thanks to the fact that presidential elections come every four years while congressional elections come every two, it often happens that a President of one party has to face a hostile Congress for half his term. Congress can block the President; the President can block Congress; neither can make its policies effective. Congress can, and does, reject the President's legislation and he must just grin and bear it. Even when the President's own party is in control of both Houses, this can happen. His whole party can «bolt 》 and vote against his bills, and both President and Congress continue to hold office as if nothing had happened.

Our system in Canada is totally different. The Prime Minister and his Cabinet are inside Parliament and responsible to it. They are not elected at all, except as members of the House of Commons, and nobody has a fixed term. Parliament and the provincial Assemblies cannot last more than five years (though provincial Legislatures can prolong their terms, and have sometimes done so), but they may last only a few months. No Government in Canada ever has to face a hostile House for more than a few days, because the House can get rid of the Government and the Government can, ordinarily, get rid of the House. If the House votes no confidence in the Government or rejects any major Government bill, either the Government resigns and makes way for a new Government which has the support of the existing House, or the Government dissolves Par- liament to get a new House which will support the existing Government.

This makes the whole Gompers policy irrelevant and futile in Canada. Our system practically rules out independent members and \& bolters 》. As Gilbert and Sullivan put it:

«When in that House M.P.'s divide. "If they've a brain and cerebellum too, "They've got to leave that brain outside, «And vote just as their leaders tell'em to.»

《Bolters » run the risk of putting the opposite party into power and losing their own seats.

In the United States, individual Congressmen and Senators vote on each bill according to their individual views. Hence, Congressman Jones deserves Labour support because his « record》 on bills of interest to Labour is «good», and Congressman Smith does not deserve Labour support because his «record» is «bad». In Canada, members of Parliament do not vote on each bill according to their own individual views. They vote with their party. Our system will not work on any other basis. Mr. Smith, M.P., has no « record». It is his party which has the « record 》.

In Canada, therefore, it is no use trying to work through individual M.P.'s. Labour inust work through a party. It has to throw out parties which are against it and put in a party which is for it. Theoretically, it could capture one of the old parties. But in practice this is impossible, because the only Canadian party which has a democratic structure and is controlled by its members is the C.C.F. The American old parties have regular Conventions to choose leaders and frame policies. Our old parties do not. The Conservative party goes back to 1854 . It never had a National Convention till 1927, and has had only two since. The Liberal party goes back to about 1873. It never had a National Convention till 1893 (and even that dit not choose the Leader), and it has had only one since, in 1919. Now it is about to have its third. In general, the old parties have Conventions, national or provincial, only when a Leader dies or resigns. No Liberal or Progressive Conservative Leader ever has to come back to the rank and file of his party at regular intervals, render an account of his stewardship, and submit himself for re-election. Party policies, except at irregular, and usually 
long, intervals, are settled by a small group of leading men.

The C.C.F., on the other hand, has a National Convention every second year and Provincial Conventions every year. Those Conventions decide the policies of the party and elect its officers. To those Conventions the Leaders are responsible. From those Conventions they must seek reelection each time.

Moreover, what is very important, only the C.C.F., among major Canadian parties, provides for the affiliation of unions as such.

In Canada, therefore, effective labour political action not only means action through a party, it means action through a new party.

These are the reasons why, in spite of the powerful influence of American tradition, the Canadian Congress of Labour has followed instead the tradition of the British unions and endorsed the C.C.F. It is also the reason why many local unions of both Congresses have affiliated with the C.C.F.

A fourth important difference between the Congresses is in their positions on Communisin. It is hardly necessary to say that neither Congress is dominated by Communists or pro-Communists. On the other hand, it is unquestionably true that both Congresses have, or have had, important constituent unions which are Communist-dominated. There are more of these in the C.C.L. than in the T.L.C. Paradoxically, however, the C.C.L. has taken a far stronger stand against Communism than the T.L.C. The Communists bitterly opposed the decision to endorse the C.C.F., and have repeatedly tried to have it reversed, but have always been overwhelmingly defeated. Their nominees for the Executive Committee also have almost invariably been overwhelmingly defeated. The last.C.C.L. Convention, in October 1947, passed three strongly anti-Communist resolutions. The first, on foreign policy, carried by 546 to 165 . The second, denouncing the Communist movement as such, and the third, reaffirming the endorsation of the C.C.F., carried without a recorded vote. No similar resolutions have been passed by any T.L.C. Convention in recent years.

One reason for this probably is that the T.L.C., being committed to non-partisanship in politics, cannot offer a coherent positive alternative to Communism. Mere anti-Communism is sterile. The C.C.L. recognizes this and always couples its denunciations of Communism and Communist policies and activities with positive proposals for dealing with the evils for which Communism professes to provide a remedy. Every one of the anti-Communist resolutions of the 1947 Convention, and notably the one endorsing the C.C.F., contained such positive proposals. As Mr. Després puts it, the officers of the Congress «ne craignent pas d'affirmer leurs convictions socialistes et d'en propager le rayonnement dans les corps affiliés au Congrès. Recrutant ses effectifs dans les industries à production massive, le Congrès du Travail est conscient de la nécessité de maintenir l'embauchage intégral dans les industries de base. De tous les groupements ouvriers, c'est certes celui qui insiste le plus sur la nécessité d'une transformation radicale de notre régime économique et social. 》

Another reason for the C.C.L.'s greater forthrightness on the question of Communism is undoubtedly the character of its SecretaryTreasurer, Mr. Pat Conroy. Mr. Conroy, upon whom St. Francis Xavier University recently confered the honorary degree of Doctor of Laws, is a devout Catholic, and a democrat through and through. He is also a member of the C.C.F., convinced that that party offers the best hope of realizing in Canada what St. Francis Xavier University has called «the divine heritage of the workers and a more Christian concept of economic society ». By the virtue of his position, but still more by his integrity, his courage, his patience and tolerance, and his outstanding ability, Mr. Conroy yields a decisive influence in shaping C.C.L. policy.

A fifth difference between the two Congresses is in their relation to the World Federation of Trade Unions. Both took part in the Conference which decided to set up the Federation. The then Secretary-Treasurer of the T.L.C., Mr. Pat Sullivan, was a member of the Provisional Committee established by the Conference. But the T.L.C. has never joined the Federation, and the C.C.L. is now, therefore, the sole Canadian member. Mr. Conroy is a member of the Executive Committee and the Council of the W.F.T.U., and took a prominent part in the recent meetings in Rome. Indeed, it is thanks to him that Canada is represented on the Executive at all. The original draft constitution of the organization would have left Canada without representation. 
Two further differences between the Congresses, perhaps relatively minor at present but not unimportant in the long run, have to do with research and workers' education. In both, the C.C.L. has been more active than the T.L.C.

Six C.C.L. unions, the Steelworkers, the Mine Workers (District 26), the Packinghouse Workers, the Electrical, Radio and Machine Workers, the Woodworkers and the Rubber Workers, have research Departments of their own. So has the Ontario Federation of Labour. In addition, the Congress itself has a Department with a full-time staff of four, which issues a regular monthly bulletin as well as providing information and drawing up briefs for the Congress, its officers and its affiliated and chartered unions. The T.L.C. has nothing of this kind, and only one of its unions has a research department in Canada.

The C.C.L. also has an active education committee which has already held two highly successful schools for workers. The first was a fortnight's summer school at Lake Couchiching, Ontario, at the end of July, 1947. The sesond was a week's winter school, at Ajax, Ontario, in January 1948, with the co-operation of the Uni- versity of Toronto. Other schools of the same sort are being planned. The T.L.C. has done nothing comparable, though it is encouraging to note that the two Congresses, the Canadian and Catholic Confederation of Labour and the independent Railway Brotherhoods are co-operating with the University of Montreal in a Labour Institute to be held in the province of Quebec.

The differences between the T.L.C. and the C.C.L. are important. No less important, however, is the underlying unity of aim and method. Both Congresses believe in democracy, and practise it. Both believe in the rule of law. Both want a stable, orderly, progressive society, moving forward through free collective bargaining, free elections, the method of trial and error and compromise. Both reject totalitarianism in all its forms. In spite of their differences, the two have found it possible to co-operate on some important matters of common concern, as in their recent joint petition for the disallowance of the Prince Edward Island Trade Union Act. It is to be hoped that, increasingly, they may be able to work together, with, in St. Paul's words, « diversities of gifts, but the same spirit ».

\section{LACK OF JOB COUNSELING RETARDS YOUNG JOB HUNTERS ${ }^{1}$}

Almost half of 1,079 young people under 22, interviewed during a survey sponsored by the California Committee for the Study of Transient Youth, migrated to California from other States or moved from one California town to another to find a job.

Almost all had difficulty findıng jobs, not only because jobs were scarce even for local boys and girls, but also because four out of five of the migrating youth had acquired no specific job skills. The young people were interviewed by public and private agencies to which they came looking for work, or because they were in need of funds, housing, recreation, or guidance.

The agencies participating in the survey, according to the report entitled "Transient Youth in California," were able to provide only emergency

(1) Labor Information Bulletin, United States Department of Labor, August 1948, p. 9. help-a bed for the night, a meal, at times in a jail or detention home, or through the Salvation Army, Travelers' Aid, or the "Y's."

The agencies cooperating in the survey recommended: (1) that counseling facilities including vocational counseling, social-work counseling, and psychiatric counseling be provided; (2) that more jobs for young and beginning workers be made available, with training furnished by both employers and trade-unions. Also recommended were special shelters for migrants, youth centers, a centralized agency for handling problems of migrant youth, and better cooperation between different areas and States in getting children back to their homes.

Copies of this report may be obtained from The California Youth Authority, 315, South Broadway, Los Angeles 13, Calif. 